\title{
Analysis of Southern Segment of Sumatran Fault Monitoring Bench Mark as Preliminary Approach in Updating Earthquake Hazard Map
}

\author{
Satrio Muhammad Alif ${ }^{1}$, Arliandy Pratama ${ }^{1}$ \\ ${ }^{1}$ Geomatics Engineering Department, Institut Teknologi Sumatera, Lampung Selatan, Lampung
}

\begin{abstract}
Sumatran Fault is one of hazard located in Sumatra Island. Southern segment of Sumatran fault is one of sources of earthquakes in Lampung Province. Hazard map is used as consideration in developing region. The source of hazard comes from stress accumulation of crust which can be derived from movement of points in surface. The study of points or monitoring bench mark to accommodate more precise fault movement or slip and stress accumulation is important for sustainable development in Lampung Province. Tool used for analysis is geographic information system especially buffer analysis. Available monitoring bench mark is analysed so that each bench mark can be classified based on its contribution of fault movement based on distance from segment of current fault. High class bench marks are prioritized to be used as survey sites to monitor fault movement. The other analysis is analysis to obtain region that lack bench mark to monitor segment of current fault or even discover new fault which is branch of segment of current fault. The result of this research is there are four high class bench marks. $58.54 \%$ of total segments of $164.020 \mathrm{~km}$ long Sumatran fault in Lampung Province is segments with no monitoring bench marks. Three most possible district to build bench mark are Airhitam, Lemong, and Ngambur District.
\end{abstract}

\section{Introduction}

Sumatran Fault generate many great earthquakes in past shown in Figure 1 [1]. Sixteen great earthquakes with magnitude more than 5 was occurred in southern segment of Sumatran Fault in last two years [2]. Monitoring of Sumatran Fault is focused on northern segment of Sumatran Fault especially after the occurrence of the 2004 Aceh earthquake which triggers activity of Sumatran Fault. Southern Segment of Sumatran Fault Monitoring is rarely conducted compared to northern segment since slip rate of northern segment is higher [3]. It makes monitoring bench marks around southern segment especially in Lampung Province is in low numbers. Fault monitoring bench marks is measured using geodetic technique to get coordinate values difference over time that generate fault parameters such as slip rate, locking depth, and segmentation [4].

Stress accumulation of crust which can be derived from movement of points or bench marks is source of hazard to update earthquake hazard map. Density of monitoring bench marks with proper position relative to the fault makes hazard map generated from more detail fault parameter is more precise. Hazard map is used as consideration in developing region. The study of points or monitoring bench mark to accommodate more precise fault movement or slip and stress accumulation is important for sustainable development in Lampung Province. This research will show the analysis of existing bench mark density to determine the classification of existing bench mark based on its position relative to Sumatran fault and region where lacks bench marks to monitor particular segment of Sumatran Fault.

\section{Method}

The process of analysing existing bench marks begins with collecting bench mark coordinated from Geospatial Agency of Indonesia and Ministry of Public Works and Housing. There are 14 existing bench marks located around southern segment of Sumatran Fault in Lampung Province in three regencies: Tanggamus, West Lampung, and West Pesisir which is shown on Figure 2. Those 14 bench mark coordinates is shown on Table 1. The coordinate refer to ITRF2008 reference frame and WGS84 reference ellipsoid. This research process is divided into two processed using those existing bench 
ICOSITER 2018 Proceeding Journal of Science and Applicative Technology

marks based on the objective of this research: classifying bench marks and determining location lacking bench marks.

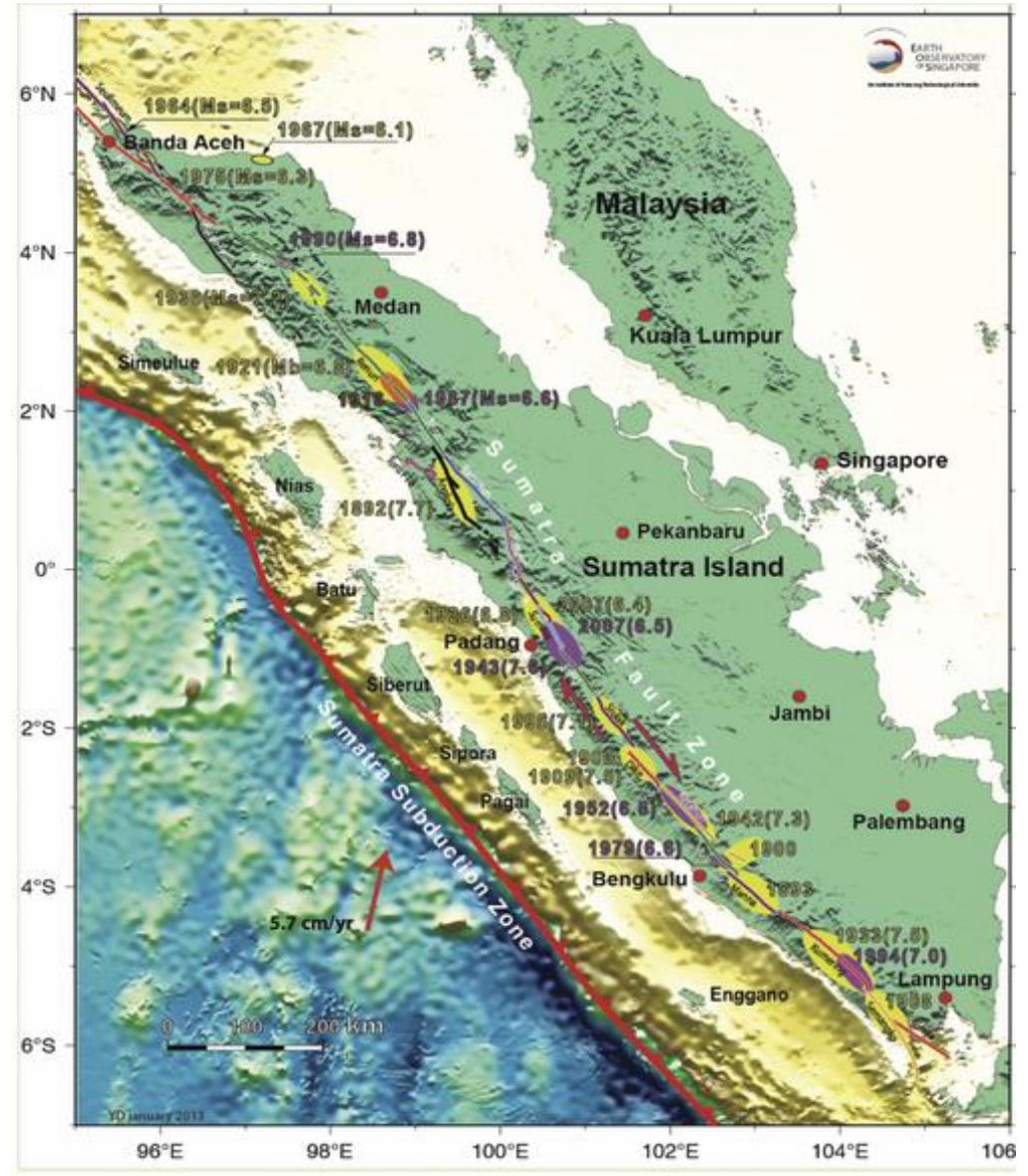

Figure 1. Sumatran Fault [1]

Table 1. Existing bench mark coordinates to monitor southern segment of Sumatran Fault

\begin{tabular}{ccc}
\hline Bench Mark Name & Longitude (o) & Latitude (o) \\
\hline BM 2 & 104.67130 & -5.51085 \\
\hline BM 3 & 104.35752 & -5.61762 \\
\hline BM 4 & 104.11054 & -5.43015 \\
\hline BM 5 & 103.94192 & -5.16513 \\
\hline BM 6 & 104.49392 & -4.99969 \\
\hline CTCN & 104.72700 & -5.91300 \\
\hline K601 & 103.96100 & -5.14300 \\
\hline K602 & 104.03800 & -5.07600 \\
\hline K603 & 104.08100 & -5.03600 \\
\hline K604 & 104.03300 & -4.93700 \\
\hline KRPN & 104.81100 & -5.59900 \\
\hline KTJW & 104.34000 & -5.60000 \\
\hline NRUI & 103.93500 & -5.18900 \\
\hline
\end{tabular}




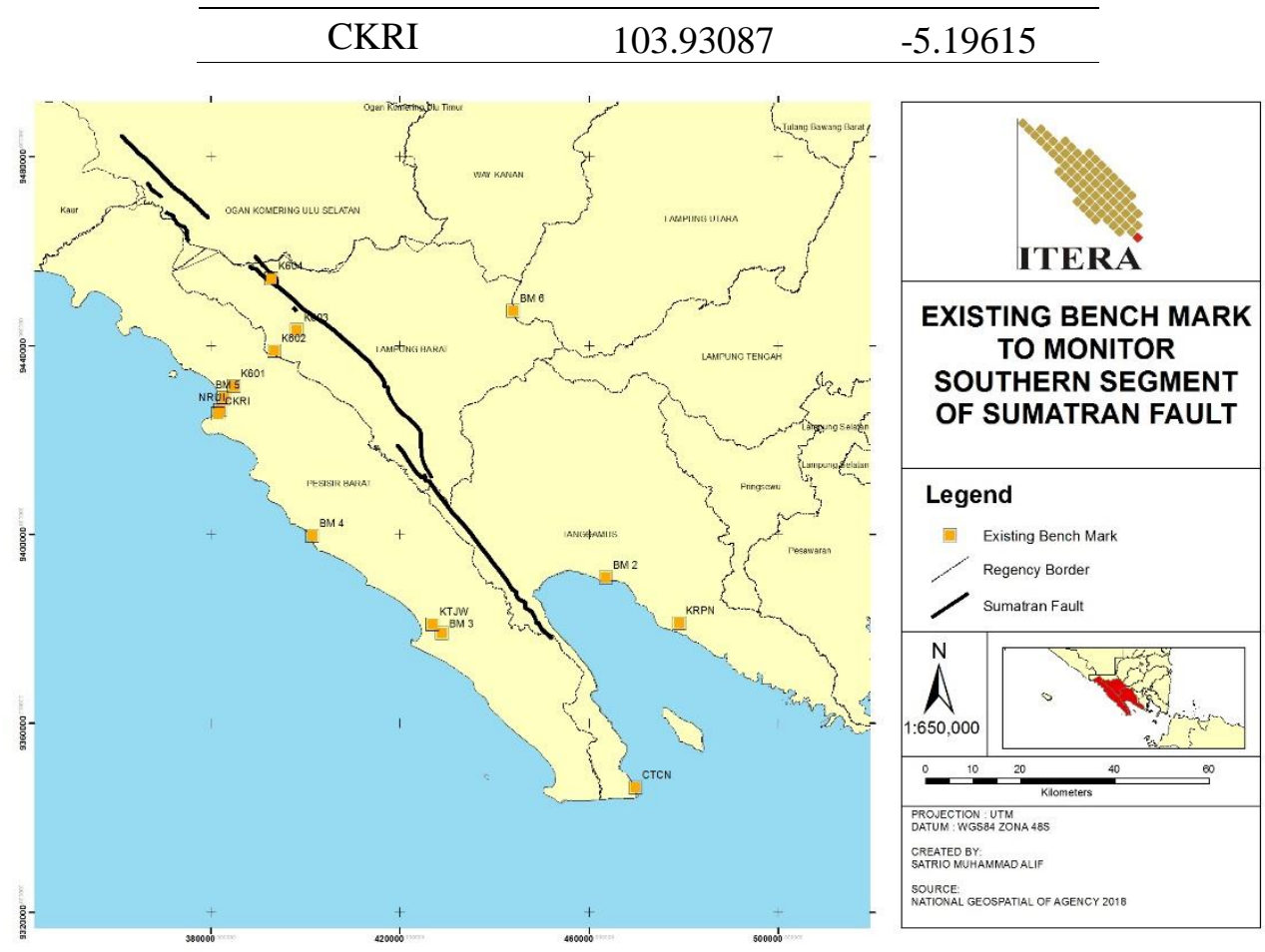

Figure 2. Existing bench mark to monitor southern segment of Sumatran Fault

\subsection{Classifying Method}

Bench mark classification is based on its perpendicular distance to Sumatran Fault. Distance threshold is determined based on trend change of Sumatran Fault function as follows [5].

$$
v_{g s f}=\frac{V}{\pi} \tan ^{-1}\left(\frac{r}{D}\right)
$$

Where $\boldsymbol{v}_{\boldsymbol{g s f}}$ is point displacement due to fault movement, $\mathrm{V}$ is fault slip rate, $\mathrm{r}$ is perpendicular distance between bench mark and fault, and D is fault locking depth. Sumatran fault is then buffered with distance threshold as buffer value. The buffer technique is generally used to reclassify based on distance [6]. Bench marks located in buffered area is classified as high class bench marks.

\subsection{Determining Method}

The process of determining region which lacks bench mark begins with projecting existing bench marks to Sumatran fault, perpendicularly. The process makes each segment of Sumatran Fault have number of projected bench marks. Thus, there are segment of Sumatran Fault with no projected bench marks. It means those segments lacks monitoring bench marks. The other segment with at least one projected bench marks is then classified based on number of projected bench marks. High class segment is segment with at least three monitoring bench marks since fault monitoring to obtain fault parameter needs at least three bench marks [4].

\section{Discussion}

The results of analysing existing bench marks related to southern segment of Sumatran fault consist of analysing the bench mark and analysing region.

\subsection{Bench Mark Classification}


ICOSITER 2018 Proceeding Journal of Science and Applicative Technology

Classification based on perpendicular distance between existing bench marks and Sumatran Fault using Sumatran Fault function with certain fault parameter from Alif [7] shown in Figure 3, with slip rate is $1.4 \mathrm{~cm} / \mathrm{yr}$ and locking depth is $16 \mathrm{~km}$.

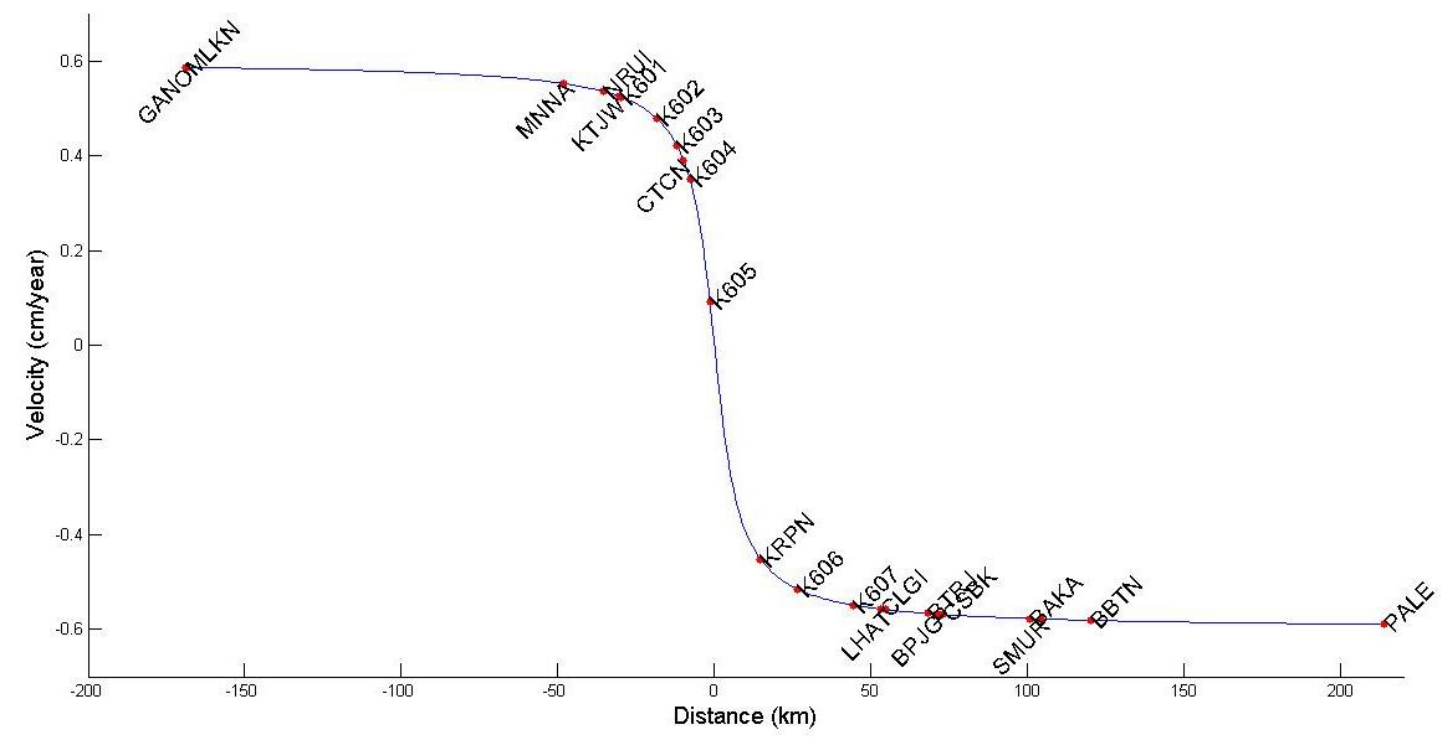

Figure 3. Sumatran fault slip model [7]

Figure 3 shows the velocity trend changes due to Sumatran fault distance value in 15 kilometres from Sumatran fault. It means threshold between bench mark which classified as high class bench marks and low class bench marks is in 15 kilometres from Sumatran fault. Bench mark with perpendicular distance less than $15 \mathrm{~km}$ is classified as high class bench marks, while the other bench marks classified as low class bench marks. Separation of those existing bench marks can be seen on Figure 4. High class bench marks means those bench marks is in high priority to be used to monitor the fault since the distance is closer to fault. 
ICOSITER 2018 Proceeding Journal of Science and Applicative Technology
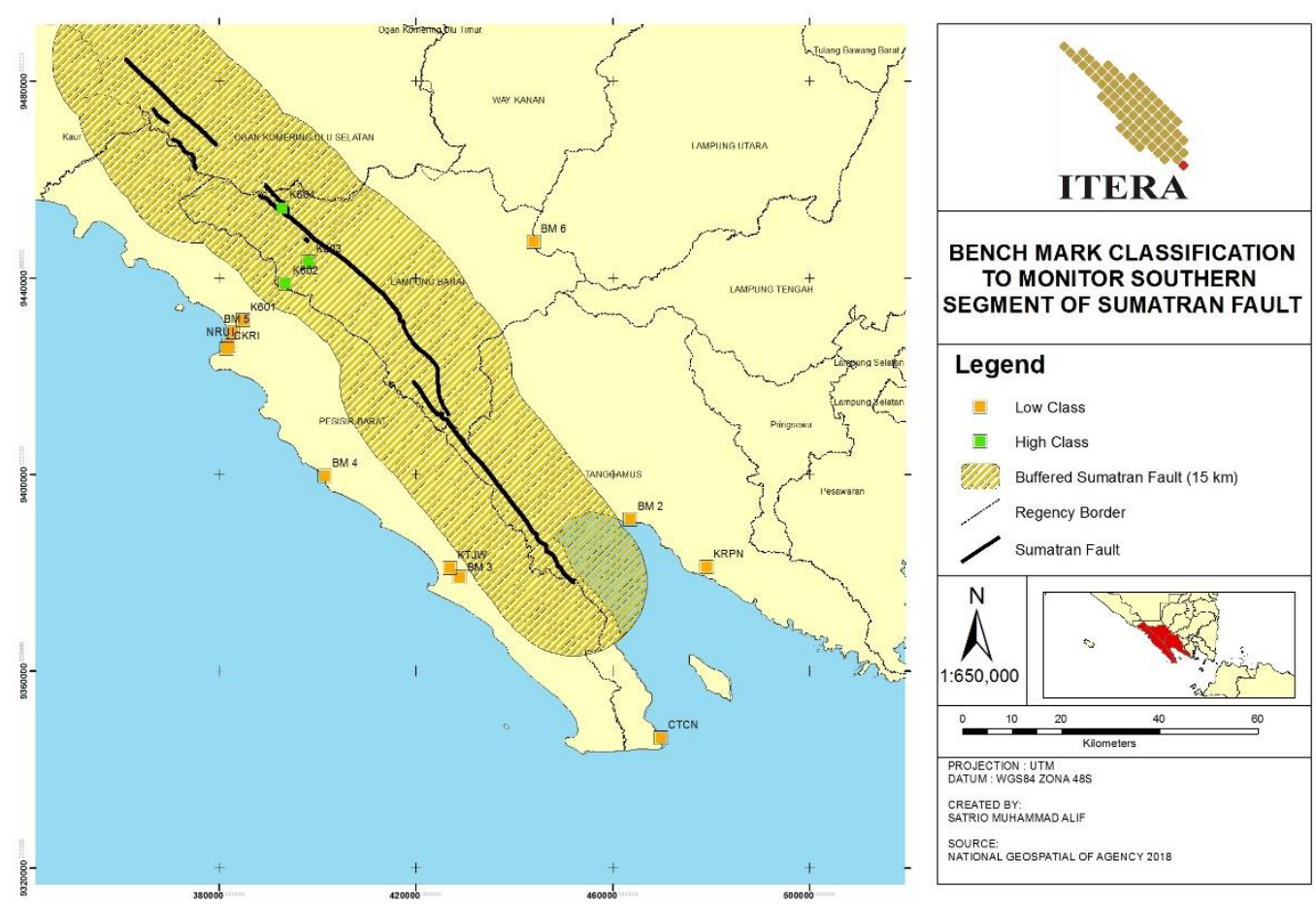

Figure 4. Bench mark classification

\subsection{Region Analysis}

Classification of segment of Sumatran fault which bench marks monitor is resulted by projecting bench mark perpendicularly method. The result is shown on Figure 5. The classification of each segment is shown on Figure 6. Red lines are segments with no monitoring bench marks. The length of those segments is $96.018 \mathrm{~km}$ or $58.54 \%$ of total segments with $164.020 \mathrm{~km}$ long. The possible location to monitor those segments with no monitoring bench marks is shown on Figure 7, 
ICOSITER 2018 Proceeding Journal of Science and Applicative Technology
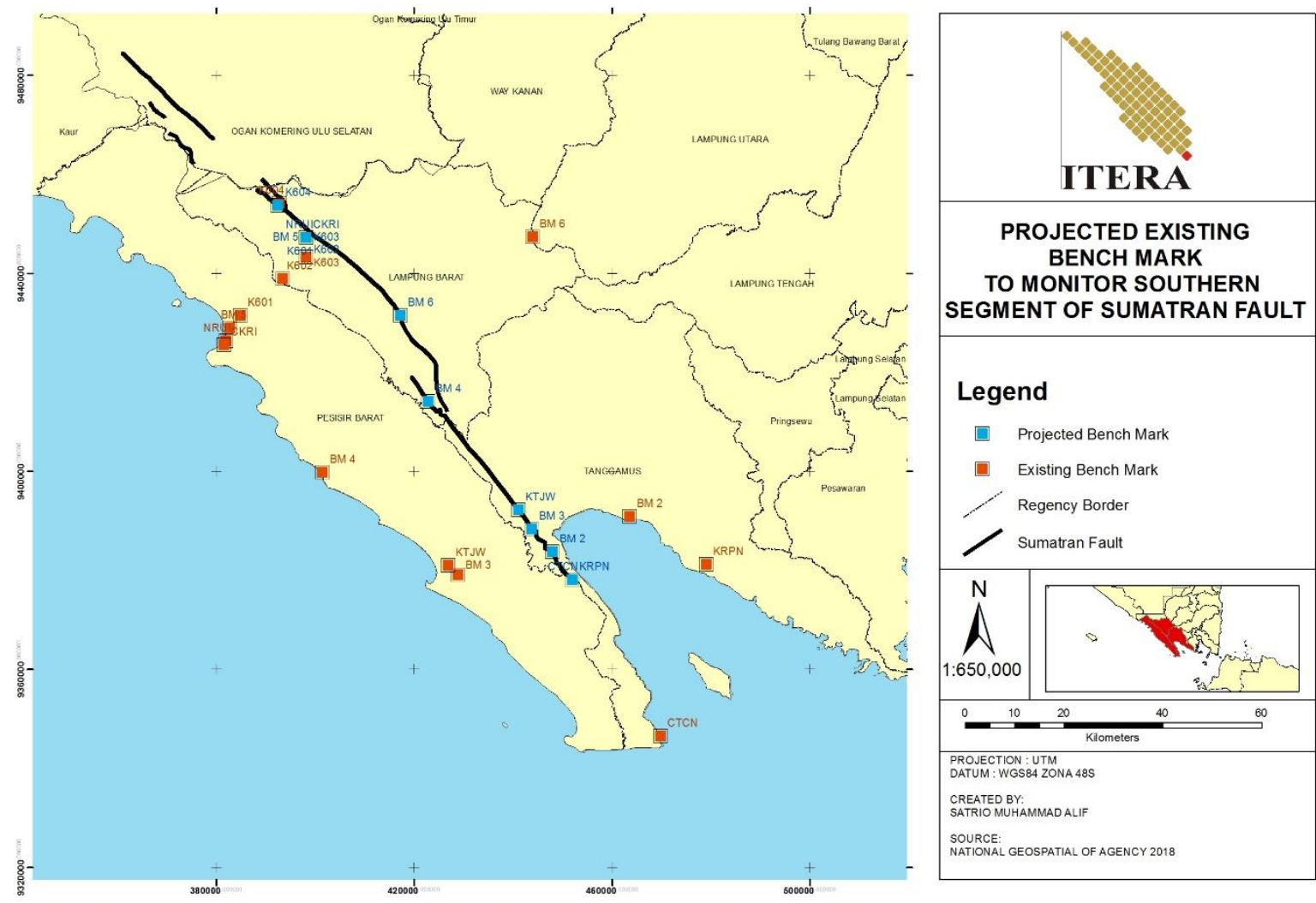

Figure 5. Existing bench marks and its projected points on Sumatran fault

Figure 7 shows possible location related to districts in three regencies: Tanggamus, West Lampung, and West Pesisir. Based on area percentage of possible location in district, the prioritized district to build bench mark is Airhitam, Lemong, and Ngambur. The summary of the area percentage of possible location in district is shown on Table 2. 
ICOSITER 2018 Proceeding Journal of Science and Applicative Technology
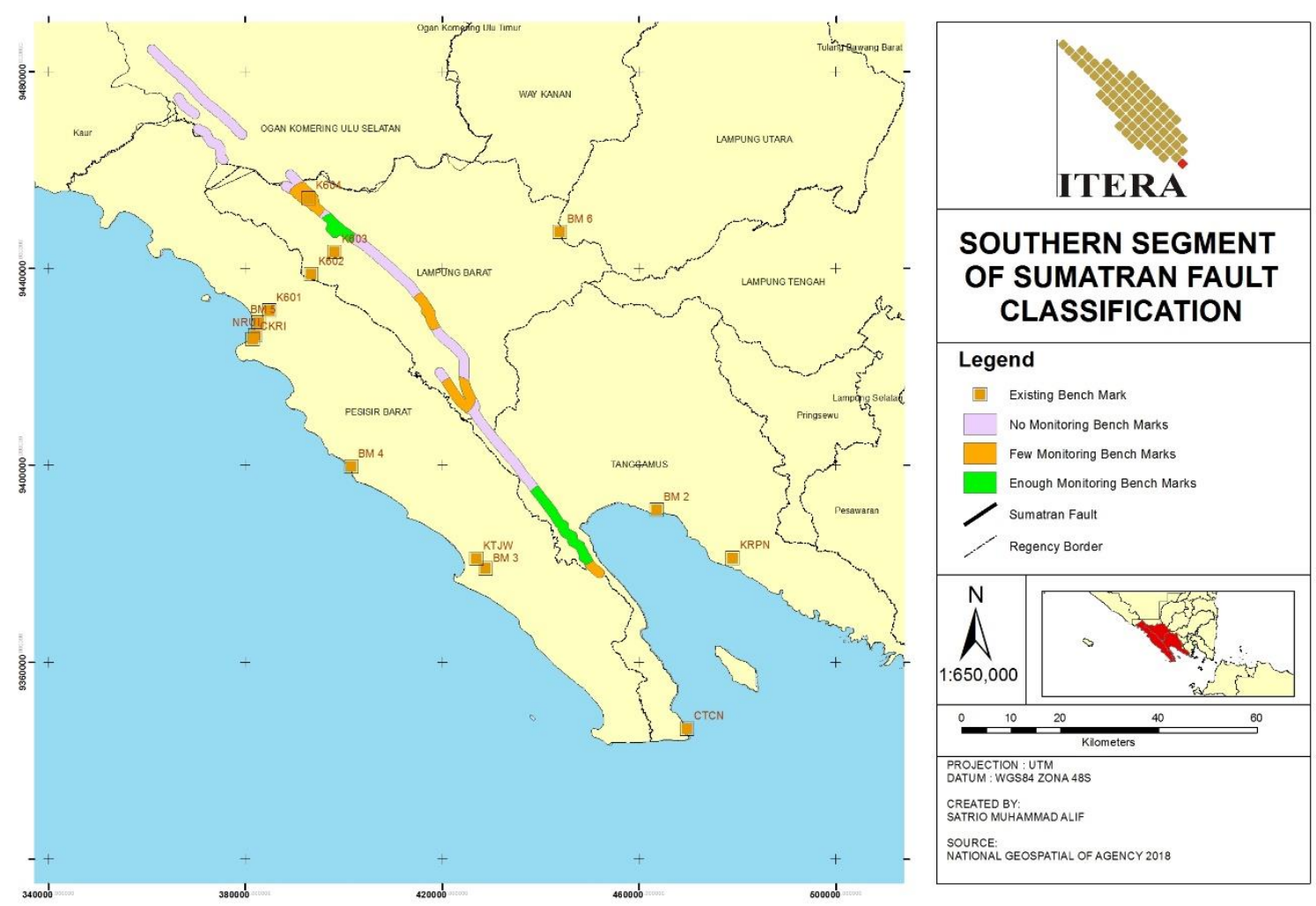

Figure 6. Classification of Sumatran fault segment based on number of bench marks projected in it
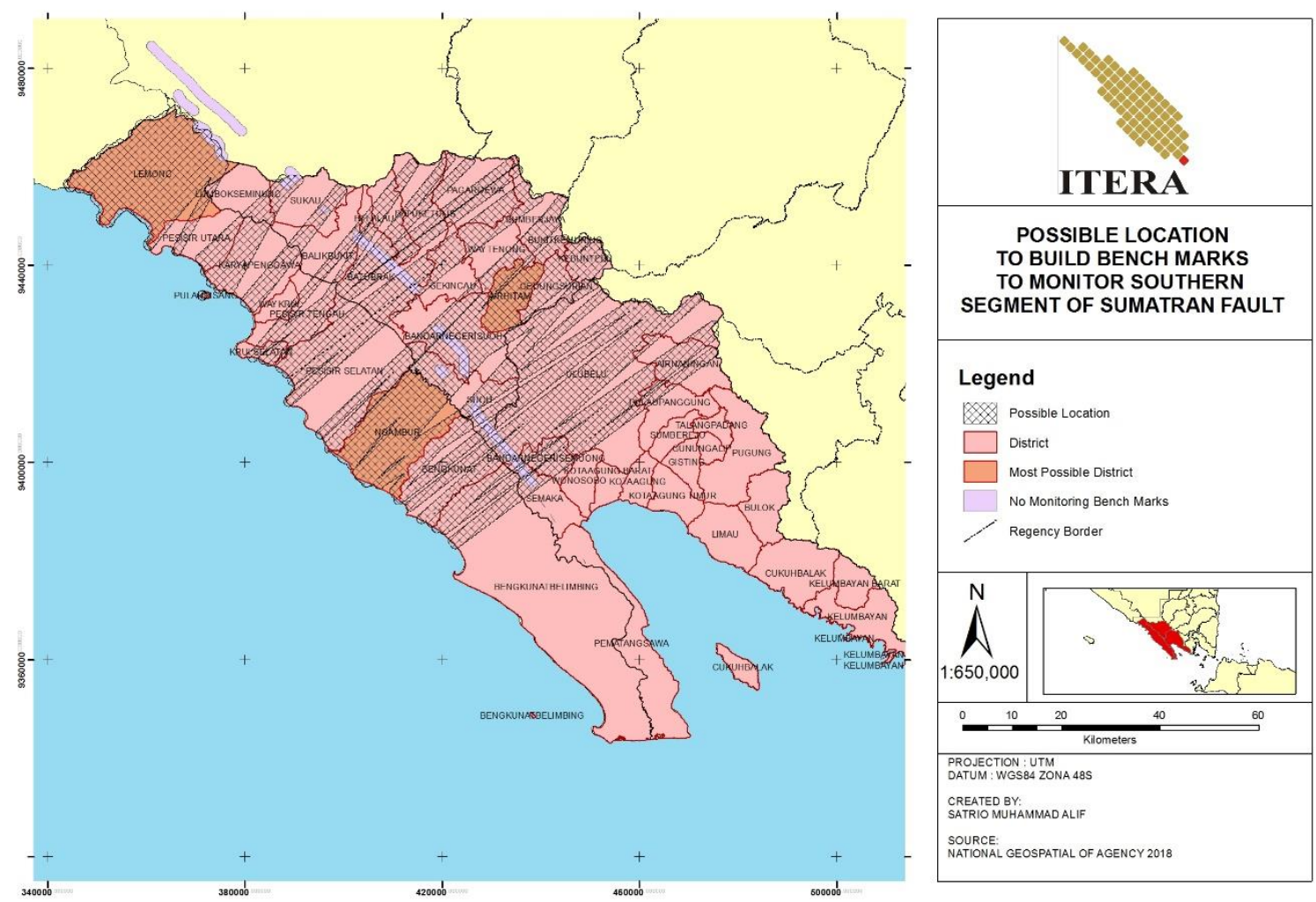

Figure 7. Possible location to monitor segments with no monitoring bench marks 
Table 2. Summary of the area percentage of possible location in district

\begin{tabular}{|c|c|c|c|}
\hline District Name & District Area (ha) & Possible Area (ha) & Percentage $(\%)$ \\
\hline Airhitam & 10812.40 & 10352.68 & $95.75 \%$ \\
\hline Lemong & 46857.63 & 43361.11 & $92.54 \%$ \\
\hline Ngambur & 33138.12 & 29897.22 & $90.22 \%$ \\
\hline Kebuntebu & 6154.90 & 5501.45 & $89.38 \%$ \\
\hline Gedungsurian & 7696.22 & 6681.58 & $86.82 \%$ \\
\hline Bandarnegerisemuong & 6498.13 & 5418.97 & $83.39 \%$ \\
\hline Pesisir Selatan & 46374.50 & 33200.28 & $71.59 \%$ \\
\hline Krui Selatan & 3316.35 & 2315.06 & $69.81 \%$ \\
\hline Ulubelu & 98486.47 & 68110.34 & $69.16 \%$ \\
\hline Bandarnegerisuoh & 26723.34 & 18435.82 & $68.99 \%$ \\
\hline Suoh & 15021.51 & 10119.02 & $67.36 \%$ \\
\hline Sumberjaya & 13043.82 & 8627.74 & $66.14 \%$ \\
\hline Pesisir Tengah & 13492.32 & 8769.51 & $65.00 \%$ \\
\hline Pulaupisang & 147.93 & 87.16 & $58.92 \%$ \\
\hline Waytenong & 12969.40 & 7311.76 & $56.38 \%$ \\
\hline Belalau & 9390.84 & 5252.20 & $55.93 \%$ \\
\hline Batuketulis & 18201.43 & 9728.82 & $53.45 \%$ \\
\hline Airnaningan & 14610.80 & 7132.56 & $48.82 \%$ \\
\hline Batubrak & 19929.02 & 9396.08 & $47.15 \%$ \\
\hline Pesisir Utara & 13524.67 & 5634.43 & $41.66 \%$ \\
\hline Karyapenggawa & 21020.82 & 8350.02 & $39.72 \%$ \\
\hline Bengkunat & 23329.53 & 8523.65 & $36.54 \%$ \\
\hline Sukau & 14610.25 & 5302.64 & $36.29 \%$ \\
\hline Balikbukit & 15940.80 & 5239.38 & $32.87 \%$ \\
\hline Semaka & 10497.42 & 2918.06 & $27.80 \%$ \\
\hline Lumbokseminung & 10829.81 & 2992.13 & $27.63 \%$ \\
\hline Pagardewa & 19770.98 & 4430.30 & $22.41 \%$ \\
\hline Waykrui & 3846.24 & 570.94 & $14.84 \%$ \\
\hline Pulaupanggung & 11139.87 & 1372.32 & $12.32 \%$ \\
\hline Sekincau & 11508.50 & 729.94 & $6.34 \%$ \\
\hline
\end{tabular}

\section{Conclusion}

The classification of bench mark and region where lack bench marks to monitor particular segment of Sumatran Fault are analysed based on existing bench mark density. There are four high class bench marks and 10 low class bench marks. 58.54\% of total segments of $164.020 \mathrm{~km}$ long Sumatran fault in Lampung Province is segments with no monitoring bench marks. Three most possible district to build bench mark are Airhitam, Lemong, and Ngambur. High class bench marks means those bench marks is in high priority to be used to monitor the fault since the distance is close to fault. The most possible district means the district is lack of bench mark and its projected location perpendicularly to the fault is on segment with no monitoring bench mark. Building bench mark to monitor each segment of 
ICOSITER 2018 Proceeding Journal of Science and Applicative Technology

southern segment of Sumatran fault with geodetic technique is important to get more fault parameter or even discover new segmentation.

\section{Acknowledgment}

This research was funded by Institut Teknologi Sumatera Smart Mandiri 2018 Research Grant Fund No. 315/IT9.A/SK/PP/2018. Authors acknowledge assistance from students of Institut Teknologi Sumatera to help processing data for this research.

\section{References}

[1] Sieh K and Natawidjaja D 2000 Neotectonics of the Sumatran fault, Indonesia Journal of Geophysical Research 10528 295-28 326

[2] USGS No date General Information [Internet document] [accessed on 18.02.2018] Site: http://earthquake.usgs.gov/earthquakes/search/

[3] Bradley K E, L Feng, E.M Hill, D H Natawidjaja, and K Sieh 2017 Implications of the diffuse deformation of the Indian Ocean lithosphere for slip partitioning of oblique plate convergence in Sumatra J. Geophys. Res. Solid Earth 122 572-591 doi: 10.1002/ 2016JB013549

[4] Lindsey EO, Fialko Y 2013 Geodetic slip rates in the southern San Andreas Fault system: Effects of elastic heterogeneity and fault geometry Journal of Geophysical Research-Solid Earth 118:689-697

[5] Beon M L 2008 Slip rate and locking depth from GPS profiles across the southern Journal of Geophysical Research

[6] Duggal Niti 2007 Retail Location Analysis: A Case Study of Burger King \& McDonald's in Portage \& Summit Counties, Ohio Kent: Department of Geography, University of Kent

[7] Alif S M, Meilano I, Gunawan E, and Efendi J 2016 Evidence of Postseismic Deformation Signal of the 2007 M8.5 Bengkulu Earthquake and the 2012 M8.6 Indian Ocean Earthquake in Southern Sumatra, Indonesia, Based on GPS Data Journal of Applied Geodesy doi: 10.1515/jag-2015-0019 